\title{
СЕМЕН ИСАКОВИЧ ТЕТЕЛЬБАУМ
}

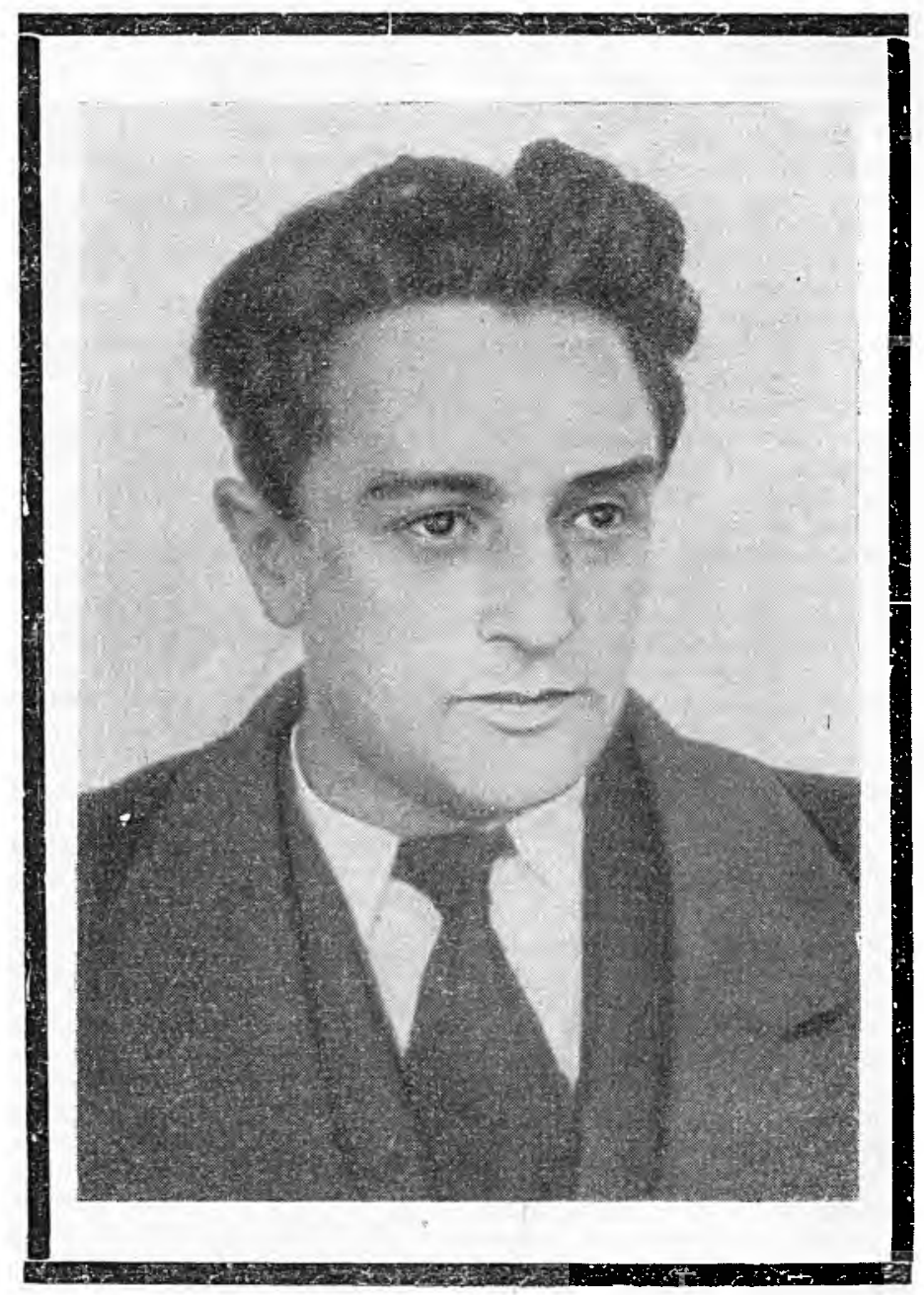

24 ноября 1958 г. скоропостижно скончался ответственный редактор журнала «Известия высших учебных заведений МВО СССР» по разделу «Радиотехника» член-корреспондент Академии наук УССР доктор техни- 
ческих наук профессор Семен Исакович Тетельбаум, выдающийся советский ученый в области радиотехники и электроники.

С. И. Тетельбаум родился в 1910 г. в семье врача. Закончив в 1932 г. Қиевский политехнический институт, он в 1934 г. защитил кандидатскую, а в 1939 г. докторскую диссертации. С 1940 г. профессор С. И. Тетельбаум бессменно заведовал кафедрой радиопередающих устройств Киевского ордена Ленина политехнического института. С 1946 г. он возглавлял Лабораторию токов высокой частоты в Институте электротехники АН УССР, а в 1948 г. был избран членом-корреспондентом АН УССР.

В течение более 25 лет профессор Тетельбаум вел большую научную и педагогическую работу. Поражала необыкновенная эрудиция Семена Исаковича, чрезвычайная глубина его научных познаний и широта научных интересов. С. И. Тетельбаум является автором 160 научных работ и изобретений, среди которых имеются работы не только по радиотехнике, радиофизике и электронике, но также исследования и в других областях науки.

В области радиопередающих устройств и теории модуляции Семеном Џ̆саковичем произведено обобщенное исследование энергетических соотношений при радиотелефонии на основании статистической обработки реалыных звуковых программ. Им были предложены новые методы повышения помехоустойчиости каналов связи путем введения частотных предыскажений, а также нспользования предельной компрессии динамического диапазона. Эти мстоды нашли широкое практическое применение в современної радиосвязи.

С. И. Тетельбаумом доказана возможность осуществления совмесгмой одиополосной передачи с несушєй, обеспечивающей при большой глубпне модуляции неискаженный прием при помощи обычных приемников с ампіитудным детектированием, что особо важно для радиовещания. Им также предложены и исследованы соответствующие схемы модуляции (оптимальная амплитудно-фазовая модуляция), внедряемые в последнее зремя в СССР и используемые также за рубежом.

Семеном Исаковичем выполнены работы по измерению характеристик рассеяния электромагнитных волн телами различной геометрической формы путем моделирования на сантиметровых и оптических волнах (моделирование на оптических волнах было применено за рубежом лишь спустя 10 лет). Им сделан ряд важных изобретений, нашедших применение в отечественной радиотехнической аппаратуре, а под его руководством выполнены практические разработки в различных областях радиоэлектроники и радиотехники. Серьезные и интересные работы выполнены Семеном Исаковичем и в области передачи энергии без проводов и теории высоконаправленных антенн. Произведен анализ услювий эффективного энергетического обмена между удаленными направленными антеннами. Показано, что высокие коэффициенты полезного действия могут быть получены при практически приемлемых размерах антенн. Исследованы оптимальные формы антенн и структура поля в луче. Исследованы некоторые перспективные применения беспроводной передачи энергии узконаправленным лучом. Эти работы закрепили за СССР приоритет в разработке проблемы передачи энергии без проводов. Полученные в области теории высоконаправленных антенн результаты широко используются в радиотехнике и неоднократно цитировались как в нашей, так и зарубежной научной литературе.

Произведено исследование условий эффективной беспроводной передачи энергии применительно к городскому высокочастотному транспорту. Исследованы потери в подземных тяговых сетях; построен и испытан 
первый опытный участок высокочастотного транспорта с большим коммунальным экипажем.

С. И. Тетельбаумом выполнено большое чнсло работ в области генерирования и применения микрорадиоволн.

Oгромное научное наследие явилось результатом того, ито в Семене I Ісаковнче удачно сочетались яркнй талант ученого с необыкновенной работоспособностью. Семен Исакович всегда работал вдохновенно, отдавая всю свою јюбовь и энергию тому делу, за которое он брался. Вся недолгая жизнь его являет собой пример подлинного творческого горения.

Многогранна и педагогическая деятельность Семена Исаковича. Будучи бессменным руководителем кафедры в течение 18 лет, деканом радиофакультета в период 1941-1943 гг. и руководителем аспирантов с 1939 г., он отдавал свои знания и силы воспитанию нового поколения советских инженеров и ученых. Им подготовлено 3 доктора и 25 кандидатов технических наук.

Семен Исакович принимал активное участие в общественной жизни. Он геоднократно избирался членом правления Всесоюзного Общества Радиотехники и Электросвязи им. А.С. Попова, зам. председателя Украинского отделения этого общегтва, руководителем секции радиовещания и телевидения, был членом редколлегий ряда журналов и сборников. Он принимал активное участие в деятельности Общества по распространению научных и политических знаний и вел большую работу по популяризации достжжений науки и техники среди трудяшихся Украинской ССР.

Профессор Тетельбаум С. И. являлся ответственным редактором Всесоюзного научно-технического журнала «Известия высших учебных заведений МВО СССР» по разделу «Радиотехника». Им проведена огромная работа по созданию журнала.

Редакционной работе он отдавался с такой же страстностью и любовью, как и научной деятельности, не шадя своего времени и своих сил. В этой работе Семен Исакович проявил себя талантливым организатором, блестящим научным редактором, чутким и внимательным другом молодых авторов и всего коллектива редакции журнала.

Советское правительство высоко оценило деятельность С. И. Тетельбаума, наградив его орденами «Красной звезды» и «Знак почета», медалью «За доблестный труд в период Великой Отечественной войны $1941-1945$ гг.» и Почетной грамотой Президиума Верховного Совета Y3. CCP.

С. И. Тетельбаум ушел от нас в полном расцвете своих творческих сил, не успев осуществить многих своих идей и замыслов. В его лице советская наука и высшая школа потеряли выдающегося ученого и чуткого педагога, отдававшего все свои силы неустанному научному твог,честву и воспитанию нового поколения советских ученых. 